\title{
PEREMPUAN PADA INDUSTRI PERHOTELAN: KINERJA ROOM MAID HOLIDAY INN EXPRESS JAKARTA WAHID HASYIM
}

\author{
Suci Sandi Wachyuni(1)*, Yanti Maharani ${ }^{(2)}$ \\ (1) Politeknik Sahid dan Kajian Pariwisata,Sekolah Pascasarjana,Universitas Gadjah Mada \\ (2) Politeknik Sahid \\ sucisandi@polteksahid.ac.id, suci.sandi.wachyuni@mail.ugm.ac.id, \\ yantymaharani@gmail.com
}

Submitted: 20 October 2020 Revised: 25 October 2020

Accepted: 27 October 2020

\begin{abstract}
ABSTRAK
Penelitian ini bertujuan untuk menganalisis kinerja perempuan di industri perhotelan khususnya di departemen tata graha (housekeeping) sebagai room maid, karena isu kesetaraan gender masih menjadi tantangan di seluruh dunia. Sampel pada penelitian ini adalah seluruh room maid berjumlah sepuluh (10) orang yang bekerja di Holiday Inn Express Jakarta Wahid Hasyim. Metode penelitian ini adalah kombinasi pendekatan kuantitatif dan kualitatif. Data kuantitatif diukur menggunakan kuesioner penilaian kinerja staff yang dinilai oleh 3 orang atasan (2 supervisor dan 1 executive housekeeper) dengan skala likert. Sedangkan data kualitatif yakni observasi dan wawancara dengan tamu dan atasan. Hasil penelitian menunjukkan Room Maid memiliki kinerja yang baik berdasarkan penilaian atasan dari 4 (empat) indikator kinerja yaitu kualitas kerja, kuantitas kerja, tanggung jawab, inisiatif, dan kerjasama. Indikator tanggung jawab memiliki nilai tertinggi, hal ini menunjukkan bahwa kinerja room maid dapat diandalkan. Secara keseluruhan tamu juga puas atas layanan yang diberikan room maid selama menginap. Penelitian ini yang menunjukkan bahwa perempuan dapat disetarakan dengan laki-laki meskipun pada pekerjaan yang didominasi aktifitas fisik. Hal ini berarti perempuan juga memiliki potensi yang sama untuk duduk di posisi manajerial suatu organisasi. Implikasi praktis dalam penelitian ini adalah saran bagi para manajemen di industri perhotelan untuk dapat memberikan kesempatan lebih luas kepada perempuan dikarenakan memiliki kinerja yang dapat diperhitungkan. Limitasi penelitian ini adalah hanya menganalisis kinerja room maid maka dari itu, penelitian lebih lanjut dapat menguji sampel yang lebih luas dan di lokasi yang berbeda.
\end{abstract}

Kata Kunci: Kesetaraan Gender, Perempuan, Perhotelan, Pariwisata, Room Maid, Housekeeping

\section{WOMEN AT HOSPITALITY INDUSTRY: ROOM MAID PERFORMANCE OF HOLIDAY INN EXPRESS JAKARTA WAHID HASYIM}

\begin{abstract}
This study aims to analyze the performance of women in the hotel industry especially in the housekeeping department as room maid because the issue of gender equality is still a challenge around the world. The sample in this study were all ten (10) maid room people who worked at the Holiday Inn Express Jakarta Wahid Hasyim. This research method is a combination of quantitative and qualitative approaches. Quantitative data were measured using a staff performance appraisal questionnaire which was assessed by 3 superiors ( 2 supervisors and 1 executive housekeeper) with a Likert scale. Meanwhile, qualitative data is observation and
\end{abstract}


interviews with guests and superiors. The results showed that Room Maid has a good performance based on the superior's assessment of 4 (four) performance indicators, namely work quality, work quantity, responsibility, initiative, and cooperation. The responsibility indicator has the highest value, this shows that the performance of the room maid is reliable. Overall guests are also satisfied with the services provided by the room maid during their stay. This research shows that women can be equal to men even in physical activity tasks. This means that women also have the same potential to have equal position in managerial level. The practical implications of this research are suggested to the management in hospitality industry in providing wider opportunities for women because they are reliable. The limitation of this study is that it only analyzes the performance of the room maid. Therefore, further research could test a wider sample at different locations.

Keywords: Gender Equality, Women, Hotel, Tourism, Room Maid, Housekeeping

\section{PENDAHULUAN}

Isu gender menjadi tantangan besar yang dihadapi oleh banyak negara pada tingkat nasional, regional, dan global. Pemaknaan istilah kesetaraan gender merujuk kepada ketimpangan posisi atau kedudukan perempuan dan laki-laki di masyarakat. Berdasarkan Global Gender Gap Index 2020, Indonesia mengalami perbaikan pada indeks kesenjangan gender, namun masih berada pada rangking 85 dari 153 negara di dunia dengan skor 0,700. Adapun pengukuran indeks kesenjangan gender dilakukan berdasarkan 14 indikator yaitu, partisipasi ekonomi dan kesempatan, pencapaian pendidikan, kesehatan dan keberlanjutan hidup, serta pemberdayaan di ranah politik. Skala pengukuran mulai dari 0.00 (tidak seimbang) hingga $1.00 \quad$ (seimbang) (Heriyanto, 2020).

Memperoleh pekerjaan yang layak merupakan hak bagi masyarakat baik perempuan maupun laki-laki untuk menjamin masa depan mereka dan keluarganya. UN Women (2013) menyebutkan bahwa pada realitasnya ketidaksetaraan gender terlihat dari performa kerja perempuan pada dunia kerja mencapai $66 \%$, memproduksi makanan sebesar $50 \%$, tetapi hanya mendapatkan $10 \%$ dari pendapatan dan hanya memiliki $1 \%$ dari property. Hal ini dikarenakan akses perempuan sangat terbatas terhadap lahan, modal, dan pendidikan dibandingkan lakilaki, kecenderungan perempuan adalah bekerja di rumah, dan perempuan menghadapi diskriminasi pada kehidupan keluarga (Santiago, 2009).

Hotel, Katering, dan Pariwisata (HKP) merupakan sektor yang juga tidak lepas dari kesenjangan gender. Meskipun adanya peningkatan partisipasi perempuan pada bidang ekonomi di banyak negara berkembang, karakteristik pekerjaan di sektor HKP tidak lebih ringan. Karakter pekerjaan di sektor-sektor ini umumnya memiliki jam kerja yang tidak teratur, bersifat sementara atau musiman, dan biasanya memberlakukan pekerjaan paruh waktu (ILO, 2009). Beberapa masalah yang sering terjadi pada sektor HKP terkait dengan kesenjangan gender antara lain ketidaksetaraan upah, dimana seringkali perempuan mendapatkan upah yang lebih rendah dibandingkan laki-laki (Thrane, 2007). Selain itu penelitian lain menunjukan adanya perbedaan kesempatan promosi antara lakilaki dan perempuan untuk posisi menajerial (Manwa \& Black, 2008).

$$
\text { Menurut Wachyuni (2020), }
$$

kesenjangan gender pada dunia pariwisata masih cukup tinggi, terlihat dari jumlah pekerja laki-laki lebih banyak daripada perempuan, khususnya sektor makanan dan minuman. Hal serupa juga terlihat pada jumlah karyawan Hotel Holiday Inn Express Jakarta Wahid Hasyim yang lebih didominasi oleh pekerja laki-laki, khususnya pada departemen tata graha. Departemen tata graha termasuk pekerjaan yang cukup berat karena membutuhkan keterampilan dan tenaga yang cukup dalam implementasinya. Berdasarkan 
latar belakang tersebut, penelitian ini bertujuan untuk menunjukkan performa kerja perempuan pada sektor perhotelan dalam rangka meningkatkan kesetaraan gender. Penelitian ini diharapkan dapat meningkatkan perspektif masyarakat terutama para pengelola hotel untuk dapat memberikan kesempatan yang sama kepada perempuan yang ingin berkarir di industri perhotelan.

\section{TINJAUAN PUSTAKA Isu Kesetaraan Gender}

Menurut Djohani (1996), gender adalah pembagian peran dan kedudukan antara lakilaki dan perempuan yang ditetapkan berdasarkan sifat perempuan dan laki-laki yang dianggap pantas menurut norma, adat istiadat, kepercayaan, atau kebiasan masyarakat. Sedangkan menurut Arbain et al (2015), gender adalah konsep yang digunakan untuk mengidentifikasi perbedaan perempuan dan laki-laki dari sudut non-biologis seperti aspek sosial, budaya, psikologis. Identitas gender adalah definisi perempuan atau lakilaki yang berinteraksi secara kompleks dengan kondisi perilaku dari proses sosialisasinya (Susanti, 2018).

Istilah kesetaraan gender menunjukkan keseimbangan pembagian tugas antara lakilaki dan perempuan (Rahminawati, 2001). Prinsip kesetaran gender adalah tidak mengijinkan adanya diskriminasi pada antara perempuan dan laki-laki. Istilah kesetaraan gender muncul pada situasi tertentu saat adanya unsur ketidakadilan yang dialami kaum perempuan. Kesetaraan gender diharapkan dapat memberikan keharmonisan dalam kehidupan antara laki-laki dan perempuan, baik dalam lingkungan keluarga maupun dalam lingkungan masyarakat secara umum.

\section{Perempuan pada Industri Perhotelan dan Pariwisata}

Perempuan berasal dari kata empu yang bermakna dihargai (Subhan, 2015). Rahman (2018) menjelaskan peran wanita terdiri dari peran tradisional, peran transisi, dan peran kontemporer. Adapun peran tradisional merupakan peran yang dilakukan sehari-hari di rumah tangga, peran transisi yaitu perannya dalam bekerja untuk mendapatkan nafkah. Sedangkan, peran kontemporer adalah peran wanita yang hanya melakukan perannya di luar rumah sebagai wanita karier. Dalam mempersempit kesenjangan gender, banyak upaya dilakukan seluruh dunia untuk menjunjung tinggi hak-hak perempuan dalam masyarakat. Di Indonesia, kesamaan hak antara perempuan dan laki-laki diatur pada Undang-Undang Ketenagakerjaan Nomor 13 Tahun 2003. Begitu juga, secara jelas tercantum pada Undang-Undang Dasar 1945 Pasal 28D bahwa setiap orang berhak mendapat imbalan dan perlakuan yang adil dan layak dalam hubungan kerja.

Sektor perhotelan dan pariwisata merupakan tantangan besar bagi perempuan jika dilihat berdasarkan karakteristik organisasi dan strukturalnya. Menurut ILO (1), sektor hotel, katering, dan pariwisata (HKP) memiliki jam kerja yang tidak teratur dan sistem shift yang tidak dapat diprediksi sehingga sulit menyesuaikannya dengan tanggung jawab dalam mengurus keluarga. Selain itu, bisnis dapat berlokasi jauh dari pemukiman penduduk, khususnya pada negara yang kurang berkembang, sehingga memakan banyak waktu dan biaya. Namun, dengan banyaknya tantangan yang harus dihadapi kaum perempuan, seringkali pekerja perempuan masih menempati level yang lebih rendah dibandingkan laki-laki (Costa, 2015).

Bekerja di industri perhotelan atau pariwisata membutuhkan energi yang ekstra (Wachyuni, 2020) dan fleksibilitas yang tinggi karena pada umumnya beroperasi 24 jam dan 7 hari dalam seminggu (Deery \& Jago, 2009). Departemen operasional hotel antara lain 
Kantor Depan (Front Office Department), Tata graha (Housekeeping Department), Tata Hidang (Food and Beverage Department), Pengolahan Makanan dan Minuman (Kitchen and Pastry), Pemasaran (Marketing Department), Akunting (Accounting Department), dan Sumber Daya Manusia (Human and Resource Department). Adapun salah satu pekerjaan yang dinilai cukup berat bagi perempuan adalah pada departemen tata graha (housekeeping) karena karakter pekerjaan didominasi oleh aktifitas fisik.

\section{Departemen Tata Graha (Housekeeping)}

Departemen Tata Graha merupakan salah satu bagian hotel yang menangani kebersihan, kerapihan, keindahan dan kenyamanan seluruh area hotel baik di dalam maupun luar gedung hotel (Hayati, 2017). Menurut Hanafi (2018), tanggung jawab housekeeping meliputi area ruang tamu, lorong, restoran dan banquet, runag kantor, loker karyawan, serta toilet karyawan dan tamu. Adapun sumber pendapat hotel yang paling besar karena tamu yang menginap mengeluarkan lebih banyak untuk sewa dibandingkan pengeluaran lainnya.

Petugas yang berkerja pada departemen housekeeping seksi kamar biasanya disebut dengan Room Attendant. Istilah bagi petugas pria disebut Roomboy sedangkan wanita disebut Room maid. Petugas pada departemen tata graha dituntut untuk memberikan pelayanan sebaik-baiknya demi memberikan kepuasan pada tamu yang menginap. Room Attendant bertugas untuk mengelola kamar, melayani tamu, dan menjalin kerja sama dengan departemen terkait (Supariasa, 2013).

\section{Kinerja}

Kinerja adalah suatu prestasi yang dicapai oleh seseorang dalam melaksanakan tugas atau pekerjaannya sesuai dengan standar kriteria yang ditetapkan dalam pekerjaan itu. Prestasi yang dicapai ini akan menghasilkan suatu kepuasan kerja yang nantinya akan berpengaruh pada tingkat imbalan (Rismawati, 2018). Sedangkan menurut Wilson (2012), adalah hasil kerja yang dicapai seseorang berdasarkan persyaratan pekerjaan (requirement).

Menurut Mangkunegara (2013), indikator kinerja terdiri dari: 1) Kualitas kerja, menunjukkan ketelitian, keterkaitan hasil kerja dengan tidak mengabaikan volume pekerjaan. Kualitas kerja yang baik dapat menghindari tingkat kesalahan dalam penyelesaian suatu pekerjaan yang dapat bermanfaat bagi kemajuan perusahaan; 2) Kuantitas kerja, menunjukkan jumlah jenis pekerjaan yang dilakukan dalam satu waktu sehingga efektif mencapai tujuan perusahaan; 3) Tanggung jawab, menunjukkan seberapa besar karyawan melaksanakan pekerjaannya dan bertanggung jawab atas perilaku kerjanya setiap hari; 4) Kerjasama, kesediaan karyawan untuk berpartisipasi dengan karyawan lain baik vertikal maupun horizontal; 5) Inisiatif, menunjukkan kesediaan karyawan dalam mengatasi masalah tanpa menunggu perintah atasan.

\section{METODE PENELITIAN}

Penelitian ini menggunakan metode kombinasi (mix-method) yang menggabungkan pendekatan kuantitatif dan kualitatif. Metode ini digunakan untuk mendapatkan pemahaman yang lebih baik. Pendekatan kuantitatif digunakan untuk mengukur kinerja Roommaid oleh semua atasan pada departemen housekeeping yaitu 2 (dua) orang Supervisor dan 1 (satu) orang Executive Housekeeper berdasarkan indikator kinerja (Mangkunegara, 2013). Skala pengukuran yang digunakan adalah skala likert 1-5 (sangat tidak setuju-sangat setuju). Sedangkan pendekatan kualitatif digunakan untuk menggali informasi lebih mendalam dengan observasi dan wawancara dengan pihak yang dianggap dapat memberikan penjelasan yaitu 1 (satu) orang atasan dan 2 (dua) tamu. Jumlah pegawai yang dinilai 
Suci Sandi Wachyuni, Yanti Maharani: Perempuan Pada Industri Perhotelan - Kinerja Room Maid Holiday Inn Express Jakarta Wahid Hasyim

adalah kesemua Roommaid di Holiday Inn Express Wahid Hasyim sebanyak 10 (sepuluh) orang. Penelitian dilakukan pada Bulan Juni-Juli 2019. Teknik analisis data kuantitatif adalah dengan mendeksripsikan nilai rerata (mean) menggunakan program SPSS v.20 dari keseluruhan penilaian. Sedangkan data kualitatif digunakan untuk menunjang hasil analisis data kuantitatif.

\section{HASIL DAN PEMBAHASAN Profil Roommaid}

Room Maid yang bertugas di Holiday Inn Express Wahid Hasyim Jakarta adalah sebanyak 10 (sepuluh) orang. Semua Room Maid (100\%) berusia muda yaitu antara 17-23 tahun. Sebanyak $80 \%$ berstatus daily worker dan hanya sebanyak $20 \%$ yang berstatus staff. Berdasarkan data lapangan, tidak ada perempuan yang menjabat level manajerial, baik Supervisor maupun Excecutive Housekeeper Adapun pendidikan terakhir kesemua roommaid $(100 \%)$ adalah SMA/SMK. Mayoritas bekerja lebih dari 1 (satu) tahun sebanyak 80\%, dan 20\% lainnya telah bekerja 1-3 tahun. Data Profil dan Karakteristik Roommaid dapat dilihat pada Tabel 1.

Tabel 1. Profil Room Maid

\begin{tabular}{|c|c|c|}
\hline Indikator & Opsi & Persentase \\
\hline \multirow{4}{*}{ Usia } & $17-23$ & $100 \%$ \\
\hline & $24-30$ & 0 \\
\hline & $31-37$ & 0 \\
\hline & $38-44$ & 0 \\
\hline \multirow{4}{*}{$\begin{array}{c}\text { Status } \\
\text { Pekerjaan }\end{array}$} & Daily Worker & $80 \%$ \\
\hline & Staff & $20 \%$ \\
\hline & supervisor & 0 \\
\hline & Ex. Housekeeper & 0 \\
\hline \multirow{4}{*}{$\begin{array}{c}\text { Pendidikan } \\
\text { terakhir }\end{array}$} & SMA/SMK & $100 \%$ \\
\hline & D1 & 0 \\
\hline & D3 & 0 \\
\hline & $\mathrm{D} 4 / \mathrm{S} 1$ & 0 \\
\hline \multirow{3}{*}{$\begin{array}{l}\text { Lama } \\
\text { Bekerja }\end{array}$} & $<1$ Tahun & $80 \%$ \\
\hline & 1-3 tahun & $20 \%$ \\
\hline & 4-6 tahun & 0 \\
\hline
\end{tabular}

\section{Hasil Penilaian Kinerja Room Maid}

Kinerja semua Room Maid dinilai oleh tiga orang atasan, yaitu 2 (dua) Supervisor dan 1 (satu) Executive Housekeeper. Ketiga penelitian ini dilakukan berdasarkan indikator kinerja Mangkunegara (2013), antara lain Kualitas Kerja, Kuantitas Kerja, Tanggung Jawab, Inisiatif, dan Kerjasama. Data hasil rata-rata penilaian atasan pada 10 (sepuluh) Room Maid pada Holiday Inn Express Wahid Hasyim Jakarta dapat dilihat pada Tabel 2.

Tabel 2. Hasil rata-rata penilaian kinerja Room

\begin{tabular}{|c|c|c|c|}
\hline $\begin{array}{l}\text { Var- } \\
\text { iabel }\end{array}$ & $\begin{array}{c}\text { Di- } \\
\text { mensi }\end{array}$ & Indikator & $\begin{array}{c}\text { Rata- } \\
\text { rata }\end{array}$ \\
\hline \multirow{11}{*}{$\begin{array}{l}\text { Kinerja } \\
\qquad(\mathrm{X})\end{array}$} & \multirow{4}{*}{$\begin{array}{l}\text { Kualita } \\
\text { s Kerja }\end{array}$} & $\begin{array}{l}\text { Karyawan } \\
\text { menguasai bidang } \\
\text { pekerjaannya }\end{array}$ & 3,70 \\
\hline & & $\begin{array}{l}\text { Karyawan teliti } \\
\text { dalam bekerja }\end{array}$ & 3,60 \\
\hline & & $\begin{array}{l}\text { Karyawan } \\
\text { memenuhi standar } \\
\text { kerja yang telah } \\
\text { ditentukan }\end{array}$ & 3,70 \\
\hline & & Total Rata-rata & 3,67 \\
\hline & \multirow{3}{*}{$\begin{array}{l}\text { Kuantit } \\
\text { as } \\
\text { Kerja }\end{array}$} & $\begin{array}{l}\text { Karyawan bekerja } \\
\text { sesuai target }\end{array}$ & 3,70 \\
\hline & & $\begin{array}{l}\text { Karyawan } \\
\text { cenderung } \\
\text { menyelesaikan } \\
\text { pekerjaan } \\
\text { sebanyak- } \\
\text { banyaknya daripada } \\
\text { terjadi penumpukan } \\
\text { kerja }\end{array}$ & 3,80 \\
\hline & & Total Rata-rata & 3,75 \\
\hline & \multirow{4}{*}{$\begin{array}{c}\text { Tanggu } \\
\text { ng } \\
\text { Jawab }\end{array}$} & $\begin{array}{l}\text { Karyawan } \\
\text { menyelesaikan } \\
\text { tugas sesuai dengan } \\
\text { waktu yang telah } \\
\text { ditetapkan (tepat } \\
\text { waktu) }\end{array}$ & 3,70 \\
\hline & & $\begin{array}{l}\text { Karyawan datang } \\
\text { dan pulang tepat } \\
\text { waktu }\end{array}$ & 4,00 \\
\hline & & $\begin{array}{l}\text { Karyawan } \\
\text { bertanggung jawab } \\
\text { atas tugas apa yang } \\
\text { dilakukan }\end{array}$ & 4,00 \\
\hline & & Total Rata-rata & 3,90 \\
\hline
\end{tabular}




\begin{tabular}{|c|c|c|}
\hline \multirow{4}{*}{ Inisiatif } & $\begin{array}{l}\text { Karyawan bersedia } \\
\text { melakukan } \\
\text { pekerjaan tanpa } \\
\text { harus diperintah } \\
\text { atau diminta dahulu } \\
\text { oleh atasan }\end{array}$ & 3,70 \\
\hline & $\begin{array}{l}\text { Bersedia } \\
\text { memperbaiki } \\
\text { kesalahan tanpa } \\
\text { harus diperintah } \\
\text { atasan }\end{array}$ & 3,70 \\
\hline & $\begin{array}{l}\text { Mampu } \\
\text { memberikan ide } \\
\text { kreatif demi } \\
\text { kemajuan } \\
\text { perusahaan }\end{array}$ & 3,60 \\
\hline & Total Rata-rata & 3,67 \\
\hline \multirow{4}{*}{$\begin{array}{c}\text { Kerjasa } \\
\text { ma }\end{array}$} & $\begin{array}{l}\text { Karyawan dapat } \\
\text { membangun } \\
\text { hubungan baik } \\
\text { sesama rekan kerja }\end{array}$ & 3,80 \\
\hline & $\begin{array}{l}\text { Karyawan dapat } \\
\text { menerima kritik dan } \\
\text { saran dari rekan } \\
\text { kerja }\end{array}$ & 3,80 \\
\hline & $\begin{array}{l}\text { Karyawan tidak } \\
\text { kesulitan bekerja } \\
\text { sama dengan rekan } \\
\text { kerja dari divisi lain }\end{array}$ & 3,70 \\
\hline & Total Rata-rata & 3,77 \\
\hline
\end{tabular}

Berdasarkan hasil rata-rata penilaian indikator kinerja kesemua Room Maid memiliki performa yang baik. Hal ini dilihat dari nilai rata-rata berada di antara 3-4 yang berarti para atasan cukup setuju-setuju dengan pernyataan pada kuesioner. Adapun nilai ratarata tertinggi kinerja adalah pada indikator tanggung jawab yaitu sebesar 3.90. Room Maid memiliki rasa tanggung jawab yang tinggi atas tugas-tugasnya, serta datang dan pulang dengan tepat waktu. Selanjutnya, nilai rata-rata tertinggi ada pada indikator kerjasama sebesar 3.77 dan diikuti dengan indikator kuantitas kerja sebesar 3,75. Sedangkan indikator kualitas kerja dan inisiatif memiliki nilai rata-rata yang sama yaitu sebesar 3.67.keamanan $\left(\mathrm{X}_{6}\right)$ sebesar $45,9 \%$, sedangkan $54,1 \%$ dipengaruhi oleh faktor-faktor lainnya.

\section{Hasil Wawancara terkait Kinerja Roomaid}

Wawancara yang dilakukan oleh peneliti adalah dengan atasan tertinggi pada departemen Housekeeping, yaitu Executive Housekeeper serta salah satu tamu yang menginap sebagai pengguna. Hasil wawancara dengan Executive Housekeeper dapat dilihat pada Tabel 3 .

\section{Hasil Wawancara dengan Executive Housekeeper (Windu Purnomo, lama Kerja 3 tahun)}

Tabel 3. Hasil wawancara dengan Executive Housekeeper






\begin{tabular}{|c|c|c|}
\hline & $\begin{array}{l}\text { perbedaan } \\
\text { tugas ini? }\end{array}$ & $\begin{array}{l}\text { perempuan bisa jadi laki- } \\
\text { lakinya lemah wanitanya } \\
\text { kuat, tapi kan mayoritas } \\
\text { secara kasat mata cowok } \\
\text { lebih kuat" }\end{array}$ \\
\hline 6 & $\begin{array}{l}\text { Adakah } \\
\text { perbedaan } \\
\text { kualitas kerja } \\
\text { antara Room } \\
\text { maid dan } \\
\text { Room Boy? }\end{array}$ & $\begin{array}{l}\text { Kadang ada. Biasanya } \\
\text { wanita jika low occupancy } \\
\text { akan lebih teliti lebih rapi } \\
\text { jika sedang kejar-kejaran } \\
\text { check-out dan back-to-back } \\
\text { dia akan banyak missing. } \\
\text { Yang penting kamarnya rapi } \\
\text { jika ada kekurangan } \\
\text { supervisor akan membantu } \\
\text { melengkapinya. }\end{array}$ \\
\hline
\end{tabular}

Executive Housekeeper menyatakan bahwa petugas yang bekerja di departemen Housekeeping, baik perempuan maupun lakilaki harus dapat bekerja gesit (cekatan). Hal ini dikarenakan pekerjaan di Departemen Housekeeping didominasi oleh pekerjaan fisik yang membutuhkan tenaga yang besar. Namun, atasan tetap membedakan aturan beban pekerjaan antara Room Maid dan Room Boy. Jumlah kamar yang harus dikerjakan oleh Room Boy adalah maksimal sebanyak 22 kamar sedangkan wanita adalah 18 kamar, dan sikap Room Boy sangat menerima perbedaan beban kerja ini. Terkait dengan kualitas pekerjaan, Excecutive Housekeeper menyatakan bahwa terkadang terdapat perbedaan pada kerapihan kamar. Room Maid memiliki hasil kerja yang lebih rapi dibandingkan Room Boy pada situasi kerja yang santai (Low Occupancy). Sedangkan pada situasi kerja yang sibuk (High Occupancy), Room Boy masih lebih unggul dibandingkan kinerja Room Maid, dikarenakan terkadang banyak hal yang kurang, Namun, hal ini disiasati oleh Supervisor untuk memastikan kamar telah siap untuk digunakan tamu.

\section{Hasil Wawancara dengan Tamu}

Peneliti melakukan wawancara dengan 2 (dua) orang tamu terkait dengan pelayanan Room Maid pada saat menginap. Hasil wawancara ini dapat digunakan sebagai validasi hasil wawancara dengan Executive Housekeeper. Selain itu, menjadi data pendukung untuk data kuantitatif. Tamu 1, berusia 40 Tahun, domisili Bandung, dan menginap di hotel untuk beristirahat. Sedangkan Tamu 2, berusia 27 Tahun, domisili Tangerang, dan menginap dengan tujuan bisnis. Hasil wawancara dapat dilihat Pada Tabel 4.

Tabel 4. Hasil wawancara dengan tamu sebagai pengguna

\begin{tabular}{|c|c|c|c|}
\hline \multirow{2}{*}{$\begin{array}{l}\mathrm{N} \\
\mathrm{o}\end{array}$} & \multirow[t]{2}{*}{ Pertanyaan } & \multicolumn{2}{|c|}{ Jawaban } \\
\hline & & Tamu 1 & Tamu 2 \\
\hline 1 & $\begin{array}{l}\text { Berapa hari } \\
\text { anda } \\
\text { menginap di } \\
\text { Holiday Inn } \\
\text { Express } \\
\text { Jakarta } \\
\text { Wahid } \\
\text { Hasyim? }\end{array}$ & $\begin{array}{l}\text { "Satu } \\
\text { saja" }\end{array}$ & "Dua hari" \\
\hline 2 & $\begin{array}{l}\text { Bagaimana } \\
\text { pelayanan } \\
\text { hotel secara } \\
\text { umum? }\end{array}$ & $\begin{array}{l}\text { "Pelayananny } \\
\text { a bagus, } \\
\text { sangat } \\
\text { membantu, } \\
\text { fasilitasnya } \\
\text { juga ok" }\end{array}$ & $\begin{array}{l}\text { "Cukup } \\
\text { baik, } \\
\text { staffnya } \\
\text { ramah" }\end{array}$ \\
\hline 3 & $\begin{array}{l}\text { Bagaimana } \\
\text { Pelayanan } \\
\text { Room Maid } \\
\text { (Housekeepe } \\
\text { r wanita) }\end{array}$ & $\begin{array}{l}\text { "Saya sempet } \\
\text { ketemu ya } \\
\text { dikoridor } \\
\text { ramah dan } \\
\text { kinerjanya } \\
\text { juga bagus" }\end{array}$ & $\begin{array}{l}\text { "Baik, } \\
\text { ramah, } \\
\text { murah } \\
\text { senyum" }\end{array}$ \\
\hline 4 & $\begin{array}{l}\text { Apa saran } \\
\text { Anda untuk } \\
\text { Pelayanan } \\
\text { yang } \\
\text { diberikan } \\
\text { oleh Room } \\
\text { Maid? }\end{array}$ & $\begin{array}{l}\text { "Tidak ada } \\
\text { mungkin } \\
\text { dipertahankan } \\
\text { saja } \\
\text { ramahnya, } \\
\text { baiknya" }\end{array}$ & $\begin{array}{l}\text { "Fasilitasny } \\
\text { a saja } \\
\text { ditingkatkan } \\
\text { " }\end{array}$ \\
\hline
\end{tabular}

Berdasarkan hasil wawancara, secara umum tamu puas dengan pelayanan yang diberikan hotel, begitu juga dengan Room Maid yang bertugas. Kedua tamu memiliki kesan yang sama, yaitu Room Maid memiliki kinerja yang bagus dan bersikap ramah. Adapun saran dari tamu untuk Room Maid yaitu agar tetap mempertahankan keramahan dan pelayanan yang baik, sedangkan tamu lainnya memberikan masukan untuk meningkatkan fasilitas hotel.

\section{Profil dan Karakteristik Room Maid}

Berdasarkan data hasil penelitian, semua Room Maid yang bertugas berusia 17-23 
tahun. Menurut Ali \& Purwandi (2017), mereka yang lahir antara tahun 1981 sampai dengan tahun 2000 disebut dengan generasi milenial yang memiliki kualitas pendidikan yang baik. Serupa dengan apa yang dikemukakan oleh Howe dan Strauss (2000), generasi milenial adalah mereka yang lahir pada tahun 1982-2000.

Saat ini generasi ini adalah komposisi terbanyak dalam pasar tenaga kerja. Dalam melakukan pekerjaan, mereka cenderung menyukai pekerjaan yang menantang dan bekerja dengan tim. Karakter pekerjaan Room Maid sangat menantang bagi perempuan dan sangat diperlukan keterampilan bekerja dengan banyak orang, baik pada departemen housekeeping itu sendiri maupun departemen lain yang terkait misalnya Front Office. Bukti bahwa Room Maid dapat bekerjasama dengan baik adalah dengan kepuasan tamu yang menginap di Hotel. Terkait dengan

Adapun dari pendidikan terakhir, semua Room Maid adalah lulusan SMA/SMK. Seperti yang disebutkan oleh Bacan \& Nuriyah (2010), hotel membutuhkan tenaga kerja lulusan SMK. Hal ini dikarenakan lulusan pendidikan kejuruan memang sudah dipersiapkan untuk bekerja dalam bidang tertentu. Melalui sistem Praktek Kerja Lapangan di industri, para Room Maid akhirnya melamar pekerjaan di Holiday Inn Wahid Hasyim. Sedangkan, berdasarkan lama kerja, mayoritas Room Maid masih baru bekerja di hotel, tepatnya kurang dari satu tahun, Hal ini dikarenakan seringnya petugas housekeeping pindah ke tempat kerja yang baru sebelum satu tahun.

Menurut hasil penelitian Onibala (2017), generasi milenial sering menganggap bahwa pekerjaan bukanlah suatu hal yang berharga dan besar sehingga cenderung tidak serius dalam melakukan pekerjaan. Selain itu, seringnya berpindah tempat kerja menjadi ciri dari generasi milenial karena seringkali mereka mencari pekerjaan yang lebih menarik dan sesuai keinginan meskipun pendapatan lebih sedikit.

\section{Perempuan dan Kinerjanya sebagai Room Maid}

Penelitian ini menunjukkan bahwa Room Maid dinilai memiliki kerja yang baik meskipun bekerja di sektor perhotelan, khususnya di departemen tata graha yang tidak terlalu mudah untuk perempuan. Bekerja di departemen tata graha membutuhkan kecekatan, keterampilan, dan banyak tenaga karena pekerjaan ini didominasi aktifitas fisik.

Hal ini membuktikan bahwa stereotip perempuan yang seringkali dipersepsikan lemah, lembut dan manja tidak benar. Meskipun stereotip tentang perempuan di masyarakat tidak mudah untuk di ubah karena telah mengendap turun temurun sejak lama, penelitian ini memberikan perspektif yang lebih terbuka tentang perempuan. Sufiarti (2013) menjelaskan bahwa karakter perempuan dan laki-laki ini lebih banyak dikonstruksikan oleh masyarakat dan telah berlangsung lama, termasuk dialektika gender yang menyebut secara fisik laki-laki lebih kuat dibandingkan perempuan dan perempuan harus bersikap lemah lembut. Namun, sebenarnya karakter tersebut dapat dipertukarkan.

Perempuan dinilai memiliki sikap tanggung jawab yang tinggi atas pekerjaannya. Terlihat pada studi ini, Room Maid dinilai selalu melakukan pekerjaan dengan tuntas sesuai beban kerja yang diberikan atasan. Nilai rata-rata indikator tanggung jawab merupakan nilai tertinggi dari indikator kinerja yang di ukur. Room maid juga memiliki keterampilan bekerjasama dengan tim, memiliki hubungan yang baik, dan dapat menerima kritik dan saran dari rekan kerja. Hal ini membuktikan bahwa, perempuan yang dinilai sebagai makhluk emosional, nyatanya dapat menerima kritik dengan baik untuk pengembangan dirinya.

Selain bertanggung jawab dan terampil bekerja dalam tim, room maid juga dinilai rajin, karena mereka cenderung melakukan pekerjaan sebanyak-banyaknya dan tidak menunda-nuda pekerjaan yang diberian atasan. Hal ini sesuai dengan anggapan masyarakat bahwa perempuan 
memiliki sifat yang rajin dan memelihara. Tapi seringkali anggapan ini tidak diasosiasikan dengan potensi perempuan bekerja di industri, namun lebih sering dipersepsikan kaum perempuan lebih cocok bekerja dirumah mengurus rumah tangga. Hal ini tentunya perlu ditegaskan, bias gender atau pandangan masyarakat terhadap perempuan bukan untuk membatasi ruang geraknya.

Indikator kualitas kerja room maid juga dinilai bagus dan memenuhi standar, meskipun hasil wawancara menunjukkan bahwa pada high occupancy, room boy masih lebih cepat dalam menyelesaikan pekerjaan. Perempuan cenderung lebih teliti dan apik dalam bekerja sehingga membutuhkan waktu lebih banyak dalam bekerja, hal ini diperkuat dengan penelitian Sapariah (2015) yang menunjukkan kinerja perempuan lebih baik dibandingkan laki-laki di bagian keperawatan. Room maid juga dinilai ramah dan memberikan pelayanan yang baik kepada tamu yang datang menginap di Hotel. Jika kepuasan tamu sebagai tujuan dari pelayanan itu sendiri telah terpenuhi, artinya kualitas layanan room maid sudah dinilai baik. Hasil penelitian ini mendukung studi terdahulu yang dilakukan oleh Wachyuni (2020) yang membandingkan kerja perempuan dan lakilaki di restoran, dan menunjukkan tidak ada pengaruh perbedaan gender terhadap kinerja karyawan.

Penelitian Cave (2010) menyebutkan bahwa memang kontribusi perempuan di sektor pariwisata cukup tinggi, tapi seringkali posisinya berada lebih rendah dari laki-laki. Perempuan banyak dipekerjakan pada level yang tidak banyak membutuhkan keterampilan dan dibayar lebih rendah dibandingkan laki-laki. Selain itu, di negara berkembang, perempuan yang menempati posisi manajerial lebih sedikit daripada di negara maju. Hal ini sesuai dengan laporan UNWTO (2019) yang menyebutkan sebanyak $54 \%$ industri pariwisata telah mempekerjakan perempuan dan $39 \%$ nya pada ekonomi yang lebih luas. Upah perempuan $14,7 \%$ lebih rendah dari laki-laki di sektor pariwisata dan $16,8 \%$ lebih rendah pada ekonomi yang lebih luas. Hal ini memperlihatkan masih adanya ketidaksetaraan gender.

Penelitian lain yang dilakukan oleh Jamali (2009) juga menyebutkan bahwa ketidaksetaraan gender juga terlihat pada wirausaha perempuan di sektor usaha pariwisata. Surveynya menunjukkan bahwa keuntungan yang didapat oleh wirausaha perempuan tidak lebih banyak dibandingkan wirausaha laki-laki. Menurut Chinomona and Maziriri (2015), hambatan utama bagi mereka dalam berbisnis adalah akses yang terbatas terhadap keuangan. Isu ketidaksetaraan gender tersebut adalah masalah serius yang harus diuraikan, karena sangat menghalangi potensi pengembangan ekonomi itu sendiri. Penelitian ini yang menunjukkan bahwa perempuan dapat disetarakan dengan laki-laki meskipun pada pekerjaan yang didominasi aktifitas fisik. Hal ini berarti perempuan juga memiliki potensi yang sama untuk duduk di posisi manajerial suatu organisasi.

Pariwisata menjadi sektor unggulan di banyak negara dunia, termasuk Indonesia. Pariwisata berkontribusi besar terhadap penerimaan devisa negara dan menurut laporan Menteri Pariwisata dan Ekonomi Kreatif, Wishnutama Kusubandio pada Tahun 2019, penerimaan devisa negara dari pariwisata mencapai nilai yang fantastis yaitu mencapai Rp 280 triliun (Susanto, 2020). Peluang bekerja di sektor pariwisata, termasuk perhotelan sangat besar dan sudah seharusnya perempuan juga memiliki kesempatan yang sama mengembangkan dirinya di sektor pariwisata, terutama kesempatan bekerja di level profesional atau manajerial. Ramchurjee (2011) menyebutkan bahwa pariwisata potensial menjadi kendaraan menuju pemberdayaan perempuan.

\section{KESIMPULAN}

Room maid memiliki kinerja yang baik berdasarkan penilaian atasan yang diukur dengan indikator kinerja. Penilaian ini juga didukung dengan kepuasan tamu yang menginap atas pelayanan yang diberikan oleh Room maid. Penelitian ini diharapkan dapat mengurai bias gender yang terjadi di 
Suci Sandi Wachyuni, Yanti Maharani: Perempuan Pada Industri Perhotelan - Kinerja Room Maid Holiday Inn Express Jakarta Wahid Hasyim

masyarakat yang telah mengendap terlalu lama. Persepsi terkait perempuan yang lemah lembut dan lebih cocok mengurus rumah tangga dipatahkan oleh penelitian ini. Meskipun pekerjaan sebagai room maid didominasi aktifitas fisik, secara keseluruhan kinerja room maid memuaskan. Potensi perempuan bekerja di industri perhotelan atau sektor pariwisata lainnya sangat dapat dipertimbangkan. Perempuan bahkan dinilai memiliki tanggung jawab yang tinggi atas pekerjaannya. Meskipun kontribusi perempuan pada sektor pariwisata meningkat, namun perempuan perlu diberikan kesempatan yang lebih luas agar dapat berkembang dan juga menjadi bagian dari pembangunan ekonomi negara.

Penelitian ini terbatas pada kinerja room maid di Holiday Inn Wahid Hasyim dengan sampel yang terbatas. Pada penelitian selanjutnya dapat menganalisis sampel yang lebih besar, membandingkannya dengan kinerja room boy, dan mungkin perlu dilakukan studi kasus di kota lain di Indonesia. Rekomendasi lainnya adalah penelitian untu mengidentifikasi tingkat pemberdayaan perempuan pada posisi manajerial di industri perhotelan atau pariwisata yang lebih luas.

\section{DAFTAR PUSTAKA}

Ali, H., \& Purwandi, L. (2017). Milenial nusantara. Gramedia Pustaka Utama.

Bacan, \& Nuriyah. (2010). Gambaran Persepsi Mahasiswa Fresh Graduate Universitas Indonesia Terhadap Kuliah Atau Bekerja Di Luar Negeri. Jurnal Humaniora: Vol.1.91-99

Cave, Peter (2010). The Role of Women in Tourism Employment With Special Reference to Antalya, Turkey. Journal of Hospitality Marketing \& Management Volume 19 No 3, 2010, https://doi.org/10.1080/1936862100359 1400

Chinomona, E. \& Maziriri, E.T. (2015). Women in action: Challenges facing women entrepreneurs in the Gauteng province of South Africa. International
Business \& Economics Research Journal, 14 (6), 835-850.

Costa, C.,F. Bakaz., Z. Breda., M. Durão., I. Carvalho., S. Caçador. (2017). Gender, Flexibility and Ideal Tourism Worker. Analls of Tourism Research, 64: 64-75. Retrieved

https://www.sciencedirect.com/scienc e/article/pii/S0160738317300427. 28 Oktober 2019

Thrane, C. (2008). Earnings differentiation in the tourism industry: Gender, human capital and socio-demographic effects. Tourism Management, 29(3), 514-524.

Deery, M., \& Jago, L. (2009). A framework for work-life balance practices: Addressing the needs of the tourism industry. Tourism and Hospitality Research, 9(2), 97-108.

Djohani, Rianingsih. (1996). Dimensi Gender dalam Pengembangan Program Secara Partisipatif, Driya Media Bandung.

Hanafi. (2018). Pengaruh Pemberian In House Training Terhadap Peningkatan Kinerja Housekeeping. Jurnal Administrasi Bisnis Vol. 62 No 2. Diakses dari http://administrasibisnis.studentjournal. ub.ac.id/index.php/jab/article/view/267 $\underline{6 / 3070}$ Pada 29 Oktober 2020

Hayati, R. (2017). Penerapan Total Quality Management Pada Room : Politeknik Bosowa : Makassar

Heriyanto, Devina. (2020). More Indonesian Women in Labor Market, Fewer in Politics: Gender Gap Report. Diakses dari

https://www.thejakartapost.com/news/2 019/12/30/more-indonesian-women-inlabor-market-fewer-in-politics-gendergap-report.html pada 29 September 2020

ILO-UNDP: Work and family: Towards new forms of reconciliation with social coresponsibility (Santiago, 2009).

Jamali, D. (2009). Constraints and opportunities facing women entrepreneurs in developing countries. Gender in Management: An International Journal, 24 (4), 232-251. 
Mangkunegara, A. A. (2013). Manajemen Sumber Daya Manusia Perusahaan. Bandung: PT. Remaja Rosdakarya.

Manwa, H., Black, N. (2002). Influence of Organizational Culture on Female and Male Upward Mobility into Middle and Senior Managerial PositionsZimbabwean Banks and Hotels. International Journal of Cross $\begin{array}{ll}\text { Cultural Management 2(3):357-373 } & \end{array}$ DOI: $10.1177 / 147059580223005$

Onibala, T. (2017). Karakteristik Karyawan Generasi Langgas Menurut Pandangan Para Pimpinan. In Conference on Management and Behavioral Studies (Vol. 318).

Rahminawati, Nan. (2001). Isu Kesetaraan Laki-Laki dan Perempuan (Bias Gender). Mimbar No. 3 Th.XVII

Ramchurjee, N.A. (2011). "Tourism" a Vehicle for Women's Empowerment: Prospect and Challenges. Diakses dari https://www.researchgate.net/publicatio n/256505214_Tourism_a_Vehicle_for_ Women's_Empowerment_Prospect_an d_Challenges tanggal 29 oktober 2020

Rismawati, Mattalata. 2018. Evaluasi Kinerja Penilaian Kinerja Atas Dasar Prestasi Kerja Berorientasi Kedepan. Makassar : Celebes Media Perkasa.

Sapariah. (2015). Analisis Pengaruh Jenis Kelamin Terhadap Kinerja Karyawan Bagian Perawatan pada PT. Mulia Bhakti Kahuripan. Retrieved http://repository.unmuhpnk.ac.id/344 /1/JURNAL\%20SAPARIAH.pdf. 06 Januari 2020.

Subhan, Z. (2015). Al-Qur'an dan Perempuan. Jakarta: Prenamedia Grup.

Sufiarti, S. (2013). Persepsi perempuan berkarir di lingkungan UPI tentang konsep kesetaraan gender. Bandung: Universitas Pendidikan Indonesia.

Supariasa. (2013). Room Section. Diakses dari

http://supariasagede.blogspot.com/2013 /12/room-maid.html pada 29 September 2020
Susanto, Vendi Yhulia. (2020). Sepanjang 2019, devisa sektor pariwisata mencapai Rp 280 triliun. Diakses dari https://nasional.kontan.co.id/news/sepa njang-2019-devisa-sektor-pariwisatamencapai-rp-280-triliun tanggal 29 oktober 2020

Susanti, Aan. (2018). Kesetaraan Gender di Indonesia. Diakses dari https://www.researchgate.net/publicatio n/329389615_Kesetaraan_gender_di_i ndonesia/link/5c09f64092851c39ebd8d 532/download pada 29 September 2020 UNWTO. (2019). Global Report Woman in Tourism. Second Edition. Retrieved https://www.eunwto.org/doi/pdf/10.18111/9789284 420384,19 Desember 2019

UN Women: Facts \& figures on women, poverty \& economics, poverty \& employment,

http://www.unifem.org/gender_issues/ women_poverty_economics/facts_figur es.php\#2 [accessed 15 February 2013].

Wachyuni, Suci Sandi. (2020). Kinerja Pramusaji Berdasarkan Gender Studi Kasus di Restoran Amuz Gourmet Jakarta. Jurnal Media Wisata Volume 18. ISSN 16935969.

Wilson, Bangun. ( 2012). "Manajemen Sumber Daya Manusia". Jakarta: Erlangga. 